Editorial

\title{
Understanding Media Control in the Digital Age
}

\author{
Olga Dovbysh ${ }^{1}$, Esther Somfalvy ${ }^{2, *}$ \\ ${ }^{1}$ Aleksanteri Institute, University of Helsinki, Finland; E-Mail: olga.dovbysh@helsinki.fi \\ ${ }^{2}$ Research Centre for East European Studies at the University of Bremen, Germany; E-Mail: somfalvy@uni-bremen.de \\ * Corresponding author
}

Submitted: 1 September 2021 | Published: 21 October 2021

\begin{abstract}
Media control comprises multifaceted and amorphous phenomena, combining a variety of forms, tools, and practices. Today media control takes place in a sphere where national politics meet global technology, resulting in practices that bear features of both the (global) platforms and the affordances of national politics. At the intersection of these fields, we try to understand current practices of media control and the ways in which it may be resisted. This thematic issue is an endeavour to bring together conceptual, methodological, and empirical contributions to revise the scholarly discussion on media control. First, authors of this thematic issue re-assemble the notion of media control itself, as not being holistic and discrete (control vs freedom) but by considering it from a more critical perspective as having various modes and regimes. Second, this thematic issue brings a "micro" perspective into understanding and theorising media control. In comparison to structural and institutional perspectives on control, this perspective focuses on the agency of various actors (objects and subjects of media pressure) and their practices, motivations, and the resources with which they exert or resist control. Featuring cases from a broad range of countries with political systems ranging from democracy to electoral authoritarian regime, this issue also draws attention to the question of how media control relates to regime type.
\end{abstract}

\section{Keywords}

digital media; freedom of expression; internet governance; media pressure; media control; political regimes

\section{Issue}

This editorial is part of the issue "Media Control Revisited: Challenges, Bottom-Up Resistance and Agency in the Digital Age" edited by Olga Dovbysh (University of Helsinki, Finland) and Esther Somfalvy (Research Centre for East European Studies at the University of Bremen, Germany).

(C) 2021 by the authors; licensee Cogitatio (Lisbon, Portugal). This editorial is licensed under a Creative Commons Attribution 4.0 International License (CC BY).

\section{Introduction}

Media control is discussed in relation to media and journalistic independence, freedom of information and expression worldwide. At the same time, media control comprises multifaceted and amorphous phenomena, made even more elusive as digital technologies blur the existing notions and create new ones about media control, its forms, and practices.

The elusiveness of the concept becomes visible in the terminology used to describe it: censorship, manipulation, instrumentalisation, influence, fraud, capture, pressure, discipline, or the "interference in journalistic autonomy" (Akhrarkhodjaeva, 2017; Goyanes \& Rodríguez-
Castro, 2019) - all of these terms are used by scholars and practitioners alike when they attempt to describe various aspects of control over mass media (Dovbysh \& Mukhametov, 2020). However, one can hardly find a clear definition of what control over media is, and what it is not.

A full account of media control is not limited to pressure initiated by political forces but also considers economic (Herman \& Chomsky, 1988/2010; Pleines, 2016) and social pressure, among others, resulting in different ways of agenda-setting, framing, and priming of media content. Moreover, the scholarly discussion of control by the state, "business," etc., should imply a nuanced study of different actors with their interests, roles, and positions in the media sphere. 
Digitalisation has made the phenomenon even more multifaceted. Digital-born practices of media control like doxing or littering and the emergence of "trolls" or "buzzers" manipulate public discourse (for Turkey, see Baloğlu, 2021; for Russia, see Kiriya, 2021; for Indonesia, see Masduki, 2021). Journalists face "digital threats" or "digital violence" through surveillance, harassment, or data mining (Henrichsen et al., 2015). Together, they have led to a "mainstreamisation" of the digital space, meaning that state media outlets take over the digital space, which had previously mainly attracted oppositional discourses (for Russia, see Kiriya, 2021). The proliferation of artificial intelligence driven tools in the media sphere led to the emergence of new actors and tools of control in the form of technological corporations and the digital products and services they provide. The power of algorithms in the decisions that they make via prioritisation, classification, association, and filtering of data leads to a media dependency on algorithms and platforms and the leverage of platform power over journalistic practices and online information dissemination (Diakopoulos, 2019).

Simultaneously, new means of resistance and adaptation to various forms of control over and manipulation in the media have emerged. Media practitioners, no longer limited by newsrooms and institutionalised media outlets, have expanded their agency through the ability to produce and disseminate content via different channels and (social media) platforms in a hybrid and fragmented media sphere. Algorithmic power results in media practices of resistance (Velkova \& Kaun, 2021) and adaptation to new forms of human-machine (inter)actions (on gatekeeping practices on the platforms, see Malinen, 2021).

The thematic issue puts forward an alternative approach to the scholarly discussion on media control in today's world in two ways. First, the authors re-assemble the notion of media control itself, as not being holistic and discrete (control vs freedom) but by considering it from a more critical perspective as having various modes and regimes.

As the idea of digital sovereignty has recently started to gain the attention of nation-states, internet governance has become a visible part of governments' activities to expand control over cyberspace. In her article, Anna Litvinenko (2021) explores Russia's strategic narrative on digital and internet sovereignty as a part of global internet governance. Based on document analysis and expert interviews, she reveals dependencies between narratives on internet policy and the elite's evaluation of the perceived benefits and threats of global connectivity. According to Litvinenko, the Russian case of internet sovereignty is an attempt to subject a highly decentralised network to tighten state regulation via a series of measures. Ilya Kiriya (2021) focuses on another means of state interference into the internet space-the isolation of oppositional discourses with the simultaneous creation of a massive flood of pro-state information. The author calls this strategy "littering the information space"
(Kiriya, 2021, p. 23). Combining direct blocking measures and massive dissemination of state-funded online news, the strategy ensures state control and domination of pro-state discourses in the digital information space. Liudmila Sivetc and Mariëlle Wijermars (2021) present another mode of control in digital space in authoritarian regimes - the internet governance by its infrastructureleveraging the power of private infrastructure owners to obtain control over content dissemination online.

Second, this thematic issue brings a "micro" perspective into understanding and theorising media control. In comparison to structural and institutional perspectives on media control, such as the ownership of media capital (Vendil Pallin, 2017) or the legal regulation of media, a "micro" perspective focuses on the agency of various actors (objects and subjects of media pressure) and their practices, motivations, and the resources with which they exert or resist control. What is the agency of journalists, media practitioners, or online activists under political pressure? What are the practices of resistance and strategies of adaptation? What are the actual challenges of media capture in the current technological environment?

Some contributions to this issue examine practices emerging in new media as technological advancement facilitates new forms of control. Uğur Baloğlu (2021) studies troll politics in Turkish Twitter, focusing on the ruling AK Party's politics on social media. In the example of the Boğaziçi University protests, the author examines how communication is suppressed through trolls and asks to what extent and how counter-trolls can intervene to create alternative discourses and shape public opinion. Masduki (2021) shows that in the case of Indonesia, the rise of digital media has resulted in new forms of control that target critical media outlets. It is characterised by the rise of non-state and societal control over digital media, where pressure is exerted by paid social-media buzzers who manipulate information and counter critical news regarding political leaders, contributing to journalist's self-censorship. Rashid Gabdulhakov (2021) explores the role of state-approved digital vigilantes in Russia. Based on the example of the Hrushi Protiv (Piggy Against) vigilante group, the author examines formations of citizens using digital media to expose "offences" carried out by fellow citizens. Such public shaming within online platforms allows the state to demonstrate a façade of civil society activism amid the silencing of certain types of critical publics while participants gain financial rewards and fame. Sanna Malinen (2021) studies volunteer moderation in Facebook groups. Practices of moderation not only shape public discussions in these groups but also regulate access to these discussions, which makes the moderators powerful though less visible gatekeepers of the digital public sphere.

Other authors focus on traditional media and examine how individual actors within such media resist pressure from their superiors or state actors. Marína Urbániková (2021) examines journalistic autonomy in the 
Slovakian public service broadcaster and classifies resistance practices that journalists use to cope with perceived interference in their work by their media organisations. Esther Somfalvy and Heiko Pleines (2021) explore instances where journalists in Ukraine resisted censorship pressure during the Yanukovich presidency, asking which factors supported their agency. They find that while the nature of competitive authoritarianism does offer journalists opportunities for critical reporting, it is their individual characteristics-including professional ethics, networks, and job mobility-which defines whether and how the respective opportunities are used.

Finally, Jan Matti Dollbaum (2021) uses media under authoritarian conditions as data for research on protest events. Comparing protest event data from Russia that are based on different sources (English-language news agencies, dissident websites, local sources), the author demonstrates that while the data sources present different pictures of the protests, the divergence is systematic and can be put to productive use.

The cases featured in this volume come from a broad range of countries with political systems ranging from democracy to electoral authoritarian regime. Media outlets are among the first targets of governments that display authoritarian tendencies: The governments' attempts to maintain the image of a functioning democracy while tilting the political playing field in their favour leads to a variety of censorship practices (Levitsky \& Way, 2010). This makes the media one of the major battlefields in political power struggles and draws attention to another dimension of media control that features prominently in the discussion, namely the question of how media control relates to regime type. Several studies have shown that in electoral or competitive authoritarian regimes, media manipulation is used more often than most other types of manipulation when regimes attempt to shift the "playing field" in their favour (Carter \& Carter, 2018; Yeşil, 2018). State-funded digital violence as means of media control leads to the restriction of press freedom, which is linked to democratic backsliding (Freedom House, 2020a, 2020b). Populist and authoritarian governments instrumentalise communication within social media platforms, where polarising and "otherising" discourses are easy to create (Grinberg et al., 2019; Poell \& van Dijck, 2014). At the same time, the platform companies themselves are fundamentally political actors that make political decisions. The algorithmic control exercised by the platform companies shapes the very notion of freedom of expression. The platforms' political influence, together with the low democratic accountability of their algorithms, lead to new facets and challenges of media control across political regimes. In sum, media control today occurs at the intersection of national politics with global technology, while heterogeneous practices of media control and the means of resisting it that we observe have emerged as a result of both features of the (global) technologies and the affordances of national politics.

\section{Acknowledgments}

This editorial was produced as part of the research project "Media Control as Source of Political Power: The Role of Oligarchs in Electoral Authoritarian Regimes," conducted by the Research Centre for East European Studies at the University of Bremen and received financial support from the Deutsche Forschungsgemeinschaft (DFG), grant No. 391270526. We are thankful to all participants of the Workshop on "Media Control as Source of Political Power in Central and Eastern Europe" in September 2019 at the Aleksanteri Institute, University of Helsinki, for their helpful feedback.

\section{Conflict of Interests}

The authors declare no conflict of interest.

\section{References}

Akhrarkhodjaeva, N. (2017). Instrumentalisation of mass media in electoral authoritarian regimes: Evidence from Russia's presidential election campaigns of 2000 and 2008. Ibidem.

Baloğlu, U. (2021). Trolls, pressure, and agenda: The discursive fight on Twitter in Turkey. Media and Communication, 9(4), 39-51.

Carter, E. B., \& Carter, B. L. (2018). Propaganda and electoral constraints in autocracies. Comparative Politics Newsletter, 28(2), 11-18.

Diakopoulos, N. (2019). Automating the news. Harvard University Press.

Dollbaum, J. M. (2021). Protest event analysis under conditions of limited press freedom: Comparing data sources. Media and Communication, 9(4), 104-115.

Dovbysh, O., \& Mukhametov, O. (2020). State information contracts: The economic leverage of regional media control in Russia. Demokratizatsiya, 28(3), 367-391.

Freedom House. (2020a). Freedom on the net 2020: Indonesia. https://freedomhouse.org/country/ indonesia/freedom-net/2020

Freedom House. (2020b). Freedom in the world 2020: Indonesia. https://freedomhouse.org/country/ indonesia/freedom-world/2020

Gabdulhakov, R. (2021). Media control and citizen-critical publics in Russia: Are some "pigs" more equal than others? Media and Communication, 9(4), 62-72.

Goyanes, M., \& Rodríguez-Castro, M. (2019). Commercial pressures in Spanish newsrooms: Between love, struggle and resistance. Journalism Studies, 20(8), 1088-1109.

Grinberg, N., Joseph, K., Friedland, L., Swire-Thompson, B., \& Lazer, D. (2019). Fake news on Twitter during the 2016 US presidential election. Science, 363(6425), 374-378.

Henrichsen, J. R., Betz, M., \& Lisosky, J. M. (2015). Building digital safety for journalism: A survey of selected 
issues. UNESCO.

Herman, E. S., \& Chomsky, N. (2010). Manufacturing consent: The political economy of the mass media. Random House. (Original work published 1988)

Kiriya, I. (2021). From "troll factories" to "littering the information space": Control strategies over the Russian internet. Media and Communication, 9(4), 16-26.

Levitsky, S., \& Way, L. A. (2010). Competitive authoritarianism: Hybrid regimes after the Cold War. Cambridge University Press.

Litvinenko, A. (2021). Re-defining borders online: Russia's strategic narrative on internet sovereignty. Media and Communication, 9(4), 5-15.

Malinen, S. (2021). Boundary control as gatekeeping in Facebook groups. Media and Communication, 9(4), 73-81.

Masduki. (2021). Media control in the digital politics of Indonesia. Media and Communication, 9(4), 52-61.

Pleines, H. (2016). Oligarchs and politics in Ukraine. Demokratizatsiya, 24(1), 105-127.

Poell, T., \& van Dijck, J. (2014). Social media and journalistic independence. In. J. Bennett \& N. Strange (Eds.),
Media independence: Working with freedom or working for free? (pp. 182-201). Routledge.

Sivetc, L., \& Wijermars, M. (2021). The vulnerabilities of trusted notifier-models in Russia: The case of Netoscope. Media and Communication, 9(4), 27-38.

Somfalvy, E., \& Pleines, H. (2021). The agency of journalists in competitive authoritarian regimes: The case of Ukraine during Yanukovich's presidency. Media and Communication, 9(4), 82-92.

Urbániková, M. (2021). Resisting perceived interference in journalistic autonomy: A case study of public service media in Slovakia. Media and Communication, 9(4), 93-103.

Velkova, J., \& Kaun, A. (2021). Algorithmic resistance: Media practices and the politics of repair. Information, Communication \& Society, 24(4), 523-540.

Vendil Pallin, C. (2017). Internet control through ownership: The case of Russia. Post-Soviet Affairs, 33(1), 16-33.

Yeşil, B. (2018). Authoritarian turn or continuity? Governance of media through capture and discipline in the AKP Era. South European Society and Politics, 23(2), 239-257.

\section{About the Authors}

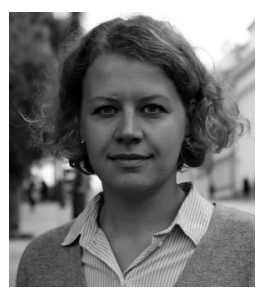

Olga Dovbysh is a postdoctoral researcher at the Aleksanteri Institute, University of Helsinki, and coordinator of the Russian Media Lab Network initiative. She works at the intersection of media studies, economic sociology, and political economy. Since January 2020, she has been working in the project Sustainable Journalism for the Algorithmic Future, which studies the challenges of algorithmic journalism in Russia and beyond.

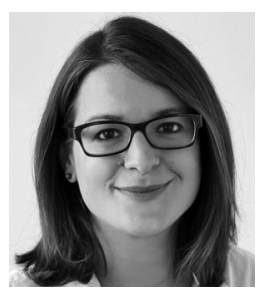

Esther Somfalvy is a research fellow at the Research Centre for East European Studies at the University of Bremen. Her research interests include comparative authoritarianism studies, political institutions (parliaments, elections), and media. 